\title{
Morphological and molecular evidence for a new species of Pseudanisakis Layman \& Borovkova, 1926 (Nematoda: Ascaridida), parasitizing Rajiformes in southern Southwest Atlantic waters
}

\author{
Manuel M. Irigoitia ${ }^{1} \cdot$ Paola E. Braicovich $^{1} \cdot$ Marisa D. Farber $^{2} \cdot$ Juan T. Timi $^{1}$
}

Received: 3 March 2017 / Accepted: 2 May 2017

(C) Springer-Verlag Berlin Heidelberg 2017

\begin{abstract}
Pseudanisakis argentinensis n. sp. is proposed to accommodate parasitic nematodes found in six skate species (Rajidae and Arhynchobatidae) examined from southern Southwest Atlantic waters. The new species differs from its congeners by the following combination of characters: a cupola on each lip, males with 8-12 pairs of precloacal genital papillae, a larger size for both males and females, a greater length-to-breadth ratio of the ventriculus and the presence of a small knob on the tip of the tail. Allometric growth was observed for several morphometric features; however, the slopes of the allometric relationships across host species exhibited non-significant differences and were considered as a strong evidence for conspecificity. Congruent results were obtained after the genetic characterization of the mitochondrial cytochrome $c$ oxidase subunit 1 gene of worms obtained from different skate species, whose values of genetic divergence (1.3) lay within the range of intraspecific variation. Previous records of specimens referred to as Pseudanisakis tricupola in skates from South American waters are regarded as conspecific with $P$. argentinensis $\mathrm{n}$. $\mathrm{sp}$.
\end{abstract}

Keywords Pseudanisakis $\cdot$ Nematoda $\cdot$ Systematics · Allometric growth $\cdot$ Psammobatis $\cdot$ Sympterygia $\cdot$ Bathyraja . Atlantoraja $\cdot$ Amblyraja $\cdot$ Argentine Sea

Manuel M. Irigoitia

mmirigoitia@mdp.edu.ar

1 Laboratorio de Ictioparasitología, Facultad de Ciencias Exactas y Naturales, Universidad Nacional de Mar del Plata (UNMdP), Instituto de Investigaciones Marinas y Costeras (IIMyC), Funes 3350, 7600 Mar del Plata, Buenos Aires, Argentina

2 Instituto de Biotecnología, Instituto Nacional de Tecnología Agropecuaria (INTA), Hurlingham, Buenos Aires, Argentina

\section{Introduction}

Members of the nematode genus Pseudanisakis Layman and Borokova, 1926, are gastrointestinal parasites of elasmobranchs (Gibbons 2010). This genus currently comprises four species ( $\mathrm{Li}$ et al. 2012), two of which have been reported in southern Atlantic and Pacific waters. These are P. tricupola Gibson, 1973, which parasitizes two species of the Arhynchobatidae from southern Southwest Atlantic waters (Gibson 1973; Tanzola et al. 1998) and a species of the Rajidae from southern Southeast Pacific waters (Fernández and Villalba 1985), and P. sulamericana Santos, Lent and Gibson, 2004, which parasitizes two species of the Arhynchobatidae in Brazilian waters (Santos et al. 2004).

Pseudanisakis was established as a subgenus of Anisakis Dujardin, 1845, by Layman and Borovkova (1926) and then raised to full generic level by Mozgovoi (1950). After a long history of nomenclatural problems, this genus was reviewed by Gibson (1973) who redescribed P. tricupola as the typespecies. Most records of this species are from Amblyraja radiata (as Raja radiata), although it has been reported from several other species of rajids from the North Sea, northern North Atlantic and the Barents Sea (Gibson 1973). In his generic revision, Gibson (1973) also described specimens obtained during an expedition carried out in 1928 in the southern Southwest Atlantic $\left(48^{\circ} 52^{\prime} \mathrm{S} ; 60^{\circ} 25^{\prime} \mathrm{W}\right)$, parasitizing Bathyraja brachyurops (as Raja brachyurops). Gibson (1973) observed some morphological and morphometric differences between specimens from $B$. brachyurops and those from $R$. radiata from the Northern Hemisphere. This author considered that these differences, observed in a small number of specimens (two males and two females), could be due to intraspecific variability and allometric growth; therefore, these specimens were identified as $P$. tricupola. Consequently, the presence of $P$. tricupola in the southern Southwester Atlantic 
was the first record of the genus in the Southern Hemisphere. Later and possibly based on the record by Gibson (1973), this species was reported in the rajid Zearaja chilensis (as Raja chilensis) in Chilean waters $\left(37^{\circ} \mathrm{S} ; 73^{\circ} 20^{\prime} \mathrm{W}\right.$ ) (Fernández and Villalba 1985) and in the arhynchobatid Sympterygia bonapartii from off the northern coasts of Argentina (Tanzola et al. 1998).

During a parasitological study of 398 skates belonging to seven species from Argentine waters, specimens of Pseudanisakis were found, providing an opportunity to corroborate the specific status of this genus in southern South American waters. Some morphometric variability was observed between worms across host species; therefore, samples were genetically characterized using the mitochondrial cytochrome $c$ oxidase subunit 1 gene (mtcoxl) and analysed to assess their specific status. Since both morphological and genetic comparisons exhibited variability at the intraspecific level, this material is described below as a new species of the genus.

\section{Materials and methods}

\section{Sample collection}

The stomachs of a total of 398 skates were examined for Pseudanisakis, including samples of the smallnose fanskate S. bonapartii Müller \& Henle, 1841, the yellownose skate Z. chilensis (Guichenot, 1848), the southern thorny skate Amblyraja doellojuradoi (Pozzi, 1935), the broadnose skate B. brachyurops (Fowler, 1910), the spotback skate Atlantoraja castelnaui (Miranda Ribeiro, 1907) and the shortfin sand skate Psammobatis normani McEachran, 1983 (Table 1). Additionally, two specimens of the multispine skate Bathyraja multispinis (Norman, 1937) were also examined (Table 1). Most fish were caught during research cruises of the Instituto Nacional de Investigación y Desarrollo Pesquero (INIDEP), covering the Argentine shelf and the Argentine-Uruguayan Common Fishing Zone, south of $34^{\circ} \mathrm{S}$. Additional samples of Am. doellojuradoi, At. castelnaui and B. brachyurops, as well as specimens of $P$. normani and B. multispinis, were obtained from commercial trawlers operating off the coast of Buenos Aires Province, Argentina. Host identification was made following the key of Cousseau et al. (2007).

Samples from research cruises were kept frozen at $-20{ }^{\circ} \mathrm{C}$ until examination, whereas those from commercial trawlers were examined immediately. In all cases, the stomachs were excised and examined under a stereomicroscope. Parasite prevalence and mean abundance were calculated following Bush et al. (1997) for each host species (Table 1). Sterne's exact $95 \%$ confidence limits were calculated for prevalence and mean abundance using Quantitative Parasitology 3.0 software (QP3.0) (Reiczigel 2003; Rózsa et al. 2000).

\section{Light and scanning electron microscopy}

Six worms (three males and three females) were washed in physiological saline solution and then fixed and stored on $4 \%$ formaldehyde until examination by scanning electron microscopy (SEM). Some specimens were preserved in 95\% ethanol for DNA-based identification.

For light microscopical studies, nematodes were cleared in lactic acid. Drawings were made with the aid of a drawing tube. For SEM, specimens were dehydrated using a graded series of ethanol washes up to $100 \%$, dried by evaporation with hexamethyldisilazane, sputter-coated with gold palladium and examined using a JEOL JSM 6460LV SEM (JEOL, Tokyo, Japan).

Measurements are given in micrometres, unless otherwise indicated, as the mean followed by the range in parentheses. Most specimens found were at larval stage, and those obtained from frozen hosts were in poor condition. Therefore, only adult specimens obtained from fresh hosts were measured.

Table 1 Composition of samples of seven skate species in the Argentine Sea and population descriptors of Pseudanisakis argentinensis n. sp. in each host species

\begin{tabular}{lclll}
\hline Host species & Number & Date of capture & Prevalence & Mean abundance \\
\hline Rajidae & & & & \\
$\quad$ Amblyraja doellojuradoi & 35 & February 25th 2015 & $14.3(4.8-30.3)$ & $0.9(0.1-3.3)$ \\
$\quad \begin{array}{l}\text { Zearaja chilensis } \\
\text { Arhynchobathidae }\end{array}$ & 77 & October 20th 2011-August 30th 2012 & $31.2(21.1-42.8)$ & $0.84(0.3-3.0)$ \\
$\quad$ Atlantoraja castelnaui & 23 & December 2nd 2011-February 8th 2017 & 0 & 0 \\
Bathyraja brachyurops & 26 & December 19th 2014-August 30th 2016 & $3.8(0.1-19.6)$ & $0.04(0.0-0.1)$ \\
Bathyraja multispinis & 2 & February 8th 2017 & $100(15.8-100)$ & $6.5(2.0-6.5)$ \\
Psammobatis normani & 14 & December 19th 2014-February 8th 2017 & $14.3(1.8-42.8)$ & $0.79(0.0-2.36)$ \\
Sympterygia bonapartii & 223 & November 23th 2010-August 14th 2015 & $27.8(22.0-34.2)$ & $1.63(0.3-7.1)$ \\
\hline
\end{tabular}

Sterne's exact $95 \%$ confidence limits are given between parentheses after prevalence and mean abundance

Number number of examined hosts 


\section{Morphometric analyses}

Gibson (1973) attributed differences in morphometric traits among specimens of $P$. tricupola to allometric growth. Therefore, allometric growth was evaluated across the worms found in different skate species. The following relationships were analysed: oesophagus length (OL) vs total length (TL), ventriculus length (VL) vs TL, VL vs ventriculus width (VW) and VL vs OL for all measured specimens. Furthermore, the relationships between spicule length (SL) vs TL and SL vs ejaculatory duct length (EL) were analysed for males, and between vulva to anterior end distance (VU) vs TL for females.

All measurements were log-transformed. The slope of the line that best fit the relationship of the variables under study was estimated using the standardised major axis (SMA) method (Warton et al. 2012). SMA is a least squares method; the line is estimated by minimizing the sum of squares of residuals from the line, and the method can be derived using the likelihood theory assuming normally distributed residuals (Sprent 1969). The major axis (MA) is the line that minimizes the sum of squares of the shortest distances from the data points to the line. The shortest distance from a point to a line is perpendicular to it, so in this method residuals are measured perpendicular to the line. The SMA is the MA calculated on standardized data, then rescaled to the original axes. This technique is equivalent to finding the first principal component axis using the correlation matrix, then rescaling the data (Warton et al. 2006).

Assuming allometric growth, the sma(y $\sim \mathrm{x}^{*}$ groups) function (package "smart" on R software) was applied to compare the SMA slopes, under the null hypothesis of equal slopes, for males and females from each host species (to analyse differential growth between the sexes), and for specimens of the same sex among different hosts (to evaluate conspecificity among specimens collected from different host species). Samples with six or more measured specimens, for each host species, were included in the analyses. Morphometric relationships between the sexes of Pseudanisakis from the same host species showed significant differences on their slopes (data not shown). Therefore, comparisons across host species were carried out for each sex individually. As no differences in the slopes were observed between worms from different host species (see Results), allometry was tested, after pooling specimens by sex, independently of the host species. Deviations from isometry were tested using the slope.test function available in the "smart" package, under the null hypothesis of a slope $=1$ (isometry condition) (Warton et al. 2006).

\section{Molecular analyses}

Nine specimens were randomly selected from host species $Z$. chilensis (three worms), S. bonapartii (two worms),
P. normani (two worms), Am. doellojuradoi (one worm) and $B$. brachyurops (one worm), and were subjected to molecular analysis. No specimens from B. multispinis were analysed because this skate was sampled subsequent to the molecular studies. DNA extraction was carried out using whole specimens with the DNeasy Blood \& Tissue ${ }^{\circledR}$ Kit (Qiagen, Hilden, Germany). The mitochondrial cytochrome $c$ oxidase subunit 1 gene (mtcoxl) was amplified using the universal DNA primers LCO1490 (forward) and HC02198 (reverse) described by Folmer et al. (1994). The polymerase chain reaction (PCR) was carried out using the following conditions: $95^{\circ} \mathrm{C}$ for $15 \mathrm{~min}$, followed by 35 cycles at $94{ }^{\circ} \mathrm{C}$ for $30 \mathrm{~s}$, $50{ }^{\circ} \mathrm{C}$ for $2 \mathrm{~min}$ and $72{ }^{\circ} \mathrm{C}$ for $2: 30 \mathrm{~min}$, followed by postamplification at $72{ }^{\circ} \mathrm{C}$ for $10 \mathrm{~min}$. All PCR reactions were set up in $50-\mu \mathrm{l}$ reactions using $10 \mu \mathrm{l}$ of DNA $(\geq 10 \mathrm{ng})$ as the template, $1 \mu \mathrm{l}(0.5 \mathrm{mM})$ of each primer and $25 \mu \mathrm{l}(2 \times)$ HotStarTaq Master Mix (Qiagen). Each PCR product was purified using QIAquick spin columns (QIAquick Gel Extraction Kit, Qiagen). Sequencing was performed at the Genomic Unit, IB-INTA.

\section{Sequence analyses}

Double-stranded mtcoxl sequences were edited manually in ProSeq 3.5 (Filatov 2002). All sequences were deposited in the GenBank database under the following accession numbers: KY765915 (from B. brachyurops); KY765916, KY765917 (from P. normani); KY765918 (from A. doellojuradoi); KY765919, KY765920 (from S. bonapartii) and KY765921KY765923 (from Z. chilensis). Generated sequences were compared against the NCBI database using the BLAST algorithm (Altschul et al. 1990).

For comparative purposes, two species of a related ascaridoid genus, Anisakis pegreffii (GenBank accession numbers KF356654.1, KF356655.1, KF356656.1) and $A$. ziphidarum (GenBank accession numbers KF214809.1, KF214810.1, KF214811.1), as well as sequences of another ascaridoid, Toxocara canis, posteriorly used as the outgroup (GenBank accession numbers EU730761.1, NC010690.1, AM411108.1), were aligned with Pseudanisakis sequences based on their inferred (in silico translated) coxl protein. Alignment was made using ClustalW (Thompson et al. 1994) as implemented in BioEdit v7.0.9 (Hall 1999).

In order to delimit potential cryptic species among the specimens of Pseudanisakis collected from different hosts, diverse approaches were used, based on their general popularity and strong performance in previous studies (Tang et al. 2014; Kekkonen et al. 2015; Díaz et al. 2016; Previšić et al. 2016). Firstly, sequence divergences were calculated using the Kimura 2-parameter (K2P) distances (Kimura 1980) of the mtcoxl gene, implemented in MEGA 6.0.6 (Tamura et al. 2013). This system usually makes a suitable metric model when genetic distances are low (Nei and Kumar 2000). The 
$\mathrm{K} 2 \mathrm{P}$ distances were calculated for all possible pairs of sequences, then the mean distances between and within groups were calculated after pooling individual parasites by host, including Anisakis spp. and T. canis in the analysis as additional groups. Genetic divergences between the two anisakids sequenced were visualized by means of non-metric multidimensional scaling (MDS) (Clarke and Gorley 2006) and hierarchical agglomerative clustering (overlaid on the MDS plots) applied to the K2P p-distance matrix. The analyses were implemented in PERMANOVA+ for PRIMER package (Anderson et al. 2008).

Secondly, the Automatic Barcode Gap Discovery (ABGD) method, which clusters sequences into hypothetical species based on differences between intraspecific and interspecific distance variation (Puillandre et al. 2012) was utilized. ABGD clustering was carried out using the K80 distance model (Kimura 1980) applying the following parameters: $\mathrm{P}_{\min }=0.001, \mathrm{P}_{\max }=0.1 ;$ Steps $20 ; \mathrm{Nb}$ bins $=20$ and a gap width $(\mathrm{X})$ of 1.5 .

Thirdly, the multi-rate Poisson Tree Processes (mPTP) model for species delimitation (Kapli et al. 2017) was employed to infer the most likely species number. This method is mainly intended for delimiting species in single-locus molecular phylogenies, modelling speciation in terms of the number of substitutions. The Hasegawa-Kishino-Yano (HKY) model with a certain fraction of invariable sites $(+\mathrm{I})$ was the model, estimated with MEGA 6.0.6, that best fitted the substitution pattern of the dataset, with ts/tv $=4.21$ and $I=0.7$. Node robustness was inferred with 1000 bootstrap replicates. The resulting maximum likelihood (ML) tree was used as the input for the MPTP model for species delimitation implemented in the Exelixis Lab web server (Zhang et al. 2013). mPTP reports were generated with the default settings using the ML solution.

\section{Results}

Six of the seven species of skates examined were parasitized by specimens of Pseudanisakis, which varied in terms of prevalence and mean abundance across the various host species (Table 1). On the other hand, A. castelnaui was found to be free of these parasites.

\section{Pseudanisakis argentinensis $\mathbf{n} . \mathbf{s p}$.}

\section{Description (Figs. 1 and 2)}

Measurements are based on combined data of specimens from S. bonapartii (12 males and 12 females), Z. chilensis (6 males and 6 females), A. doellojuradoi ( 6 males and 6 females), B. multispinis (2 males and 1 female) and $P$. normani ( 2 male and 3 females). Measurements discriminated by host species are given in Table 2 . The only specimen found in B. brachyurops (female) was destined for molecular analysis and not measured.

General. Medium to large nematodes. Maximum width at about mid-body. Head with three low lips, each bearing pronounced distal dome-shaped projection (cupola); dorsal lip bearing a typical pair of large double papillae and ventrolateral lips possessing single double papilla, single small papilla and amphid (Figs. 1b, c and 2a-c). Interlabia absent. Lips with distal ridge (vellum) armed with acuminate denticles; ridges of all three lips form single subtriangular ring of 60 87 denticles surrounding tri-radiate mouth (Figs. $1 \mathrm{~b}$ and $2 \mathrm{a}-$ d). Excretory pore just posterior to nerve ring. Oesophagus narrow, long, broadening slightly posteriorly. Ventriculus oval, slightly wider than the posterior region of oesophagus. Nerve ring at $15.2 \%(3.2-25.3)$ of oesophageal length (Fig. 1a, c). Lateral alae (Fig. 2e) very narrow, extending from near anterior end to caudal region. Cuticle with fine transverse striations (Fig. 2a, e). Tail of both sexes conical, ending in small knob (Figs. 1f-I and 2g-j).

Male [based on 28 mature specimens]. Body $33.1 \mathrm{~mm}$ (9.152.4) long, 726 (180-1120) in maximum width. Oesophagus $3.9 \mathrm{~mm}$ (1.3-6.0) long, representing $12.5 \%$ (4.7-22.7) of body length; 120 (43-410) wide at level of nerve ring and 222 (63$350)$ at oesophago-ventricular junction. Ventriculus 800 (313$1450)$ long, 295 (85-570) wide. Nerve ring and excretory pore 596 (360-770) and 663 (420-850), respectively, from anterior extremity. Posterior end of body curves ventrally. Glandular ejaculatory duct 1750 (750-2580) long. Spicules slender, almost equal in length, 1124 (688-1580) representing 66.9\% (48.9-91.7) of ejaculatory duct length and 3.6\% (2.4-8.0) of body length (Fig. 1h). Gubernaculum absent. Tail conical, 241 (140-320) in length (Figs. 1i and 2j). Caudal papillae 13-17 pairs, including 8-12 precloacal pairs (Fig. 1h) and 5 postcloacal pairs; the latter arranged as 2 dorso-lateral pairs and 3 ventro-lateral pairs; small phasmid between second ventro-lateral and first dorso-lateral papillae (Figs. 1i and 2i, j). Precloacal papillae gradually decrease in height anteriorly; posterior papillae slightly protruded; anterior papillae level with body surface (Fig. 2k-p).

Female [based on 28 gravid specimens]. Body $50.6 \mathrm{~mm}$ (10.5-83.9) long, 947 (200-1500) in maximum width. Oesophagus $4.6 \mathrm{~mm}(1.7-5.9)$ long, representing 10.2\% (6.7-20.4) of body length; width 44 (30-320) at level of nerve ring and 293 (75-580) at oesophago-ventricular junction. Ventriculus 874 (250-1500) long, width 377 (88-640). Nerve ring and excretory pore 657 (380-930) and 727 (440990), respectively, from anterior extremity. Uterus monodelphic, opisthodelphic. Vulva slit-like, $12.7 \mathrm{~mm} \mathrm{(4.0-}$ 21.0) from anterior extremity, at $27.1 \%(20.0-38.5)$ of body length (Figs. 1e and 2f). Vagina muscular, directed posteriorly. Eggs suboval to almost rounded, 89 (80-93) long, 78 (70-90) wide (Fig. 1d). Posterior end of body curves ventrally. Tail 1155 (350-1680) long, bears pair of small phasmids (Fig. 1f). 


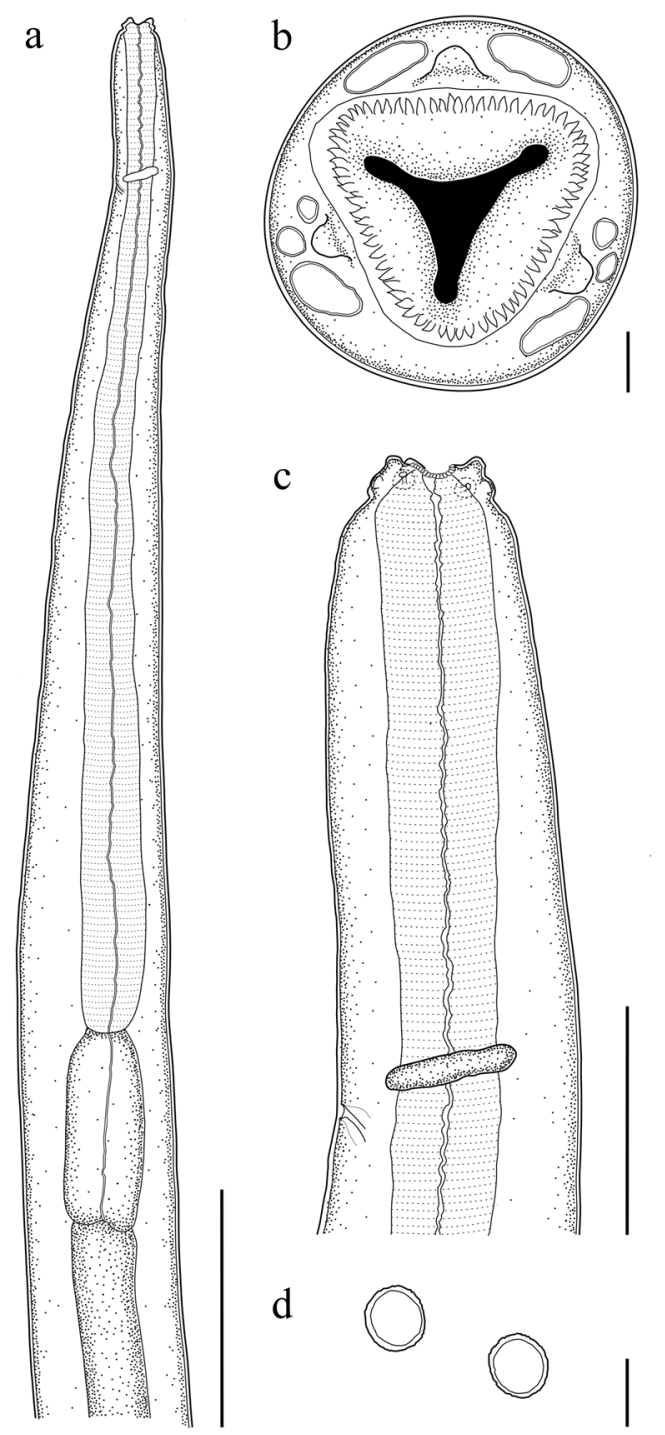

Fig. 1 Pseudanisakis argentinensis n. sp. a Anterior end, lateral view. b Anterior end, apical view. c Detail anterior end, lateral view. d Egg. e Vulva and vagina, lateral view. $\mathbf{f}$ Posterior end of female, lateral view. $\mathbf{g}$

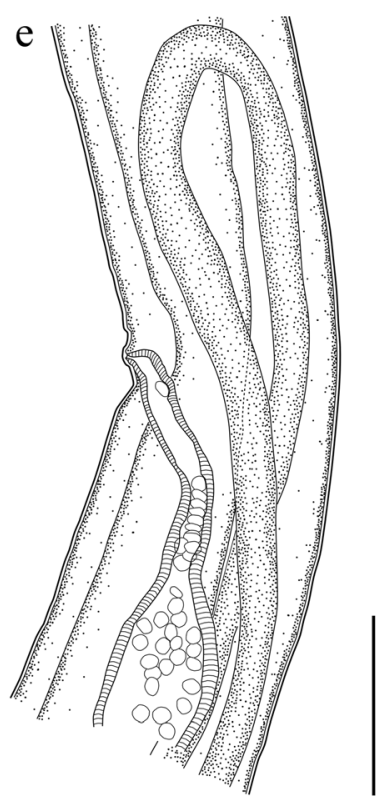

$\mathrm{g}$
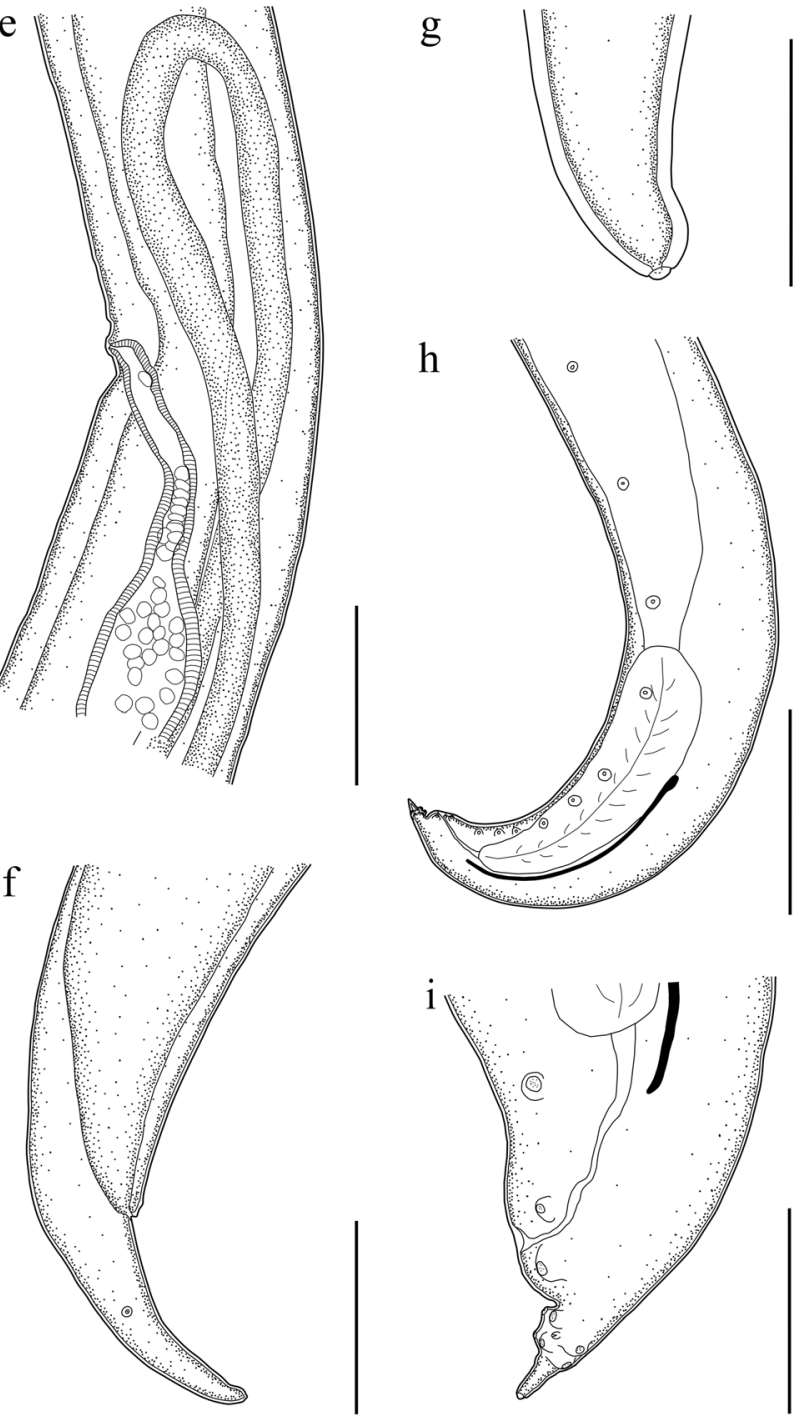

Tail of female. $\mathbf{h}$ Posterior end of male, lateral view. $\mathbf{i}$ Tail of male. Scale bars: $1000 \mu \mathrm{m}$ : a, e, f, h $20 \mu \mathrm{m}: \mathbf{b} ; 250 \mu \mathrm{m}: \mathbf{c}, \mathbf{g}, \mathbf{i} ; 100 \mu \mathrm{m}: \mathbf{d}$

\section{Site: Stomach}

Type-specimens: Deposited in the Helminthological Collection of the Museo de La Plata (MLP-He), La Plata, Argentina. Holotype MLP-He coll. No. 7310 (male). Allotype MLP-He coll. No. 7311 (female). Paratypes MLPHe coll. No. 7312 (five males and five females from S. bonapartii), MLP-He coll. No. 7313 (two males and two females from Z. chilensis), MLP-He coll. No. 7314 (two males and two females from B. multispinis), MLP-He coll. No. 7315 (two males and two females from A. doellojuradoi), MLP-He coll. No. 7316 (two males and two females from P. normani).

Etymology: The specific name is derived from the country where the type-locality (waters off Mar del Plata, Buenos Aires Province, Argentina) is located. 

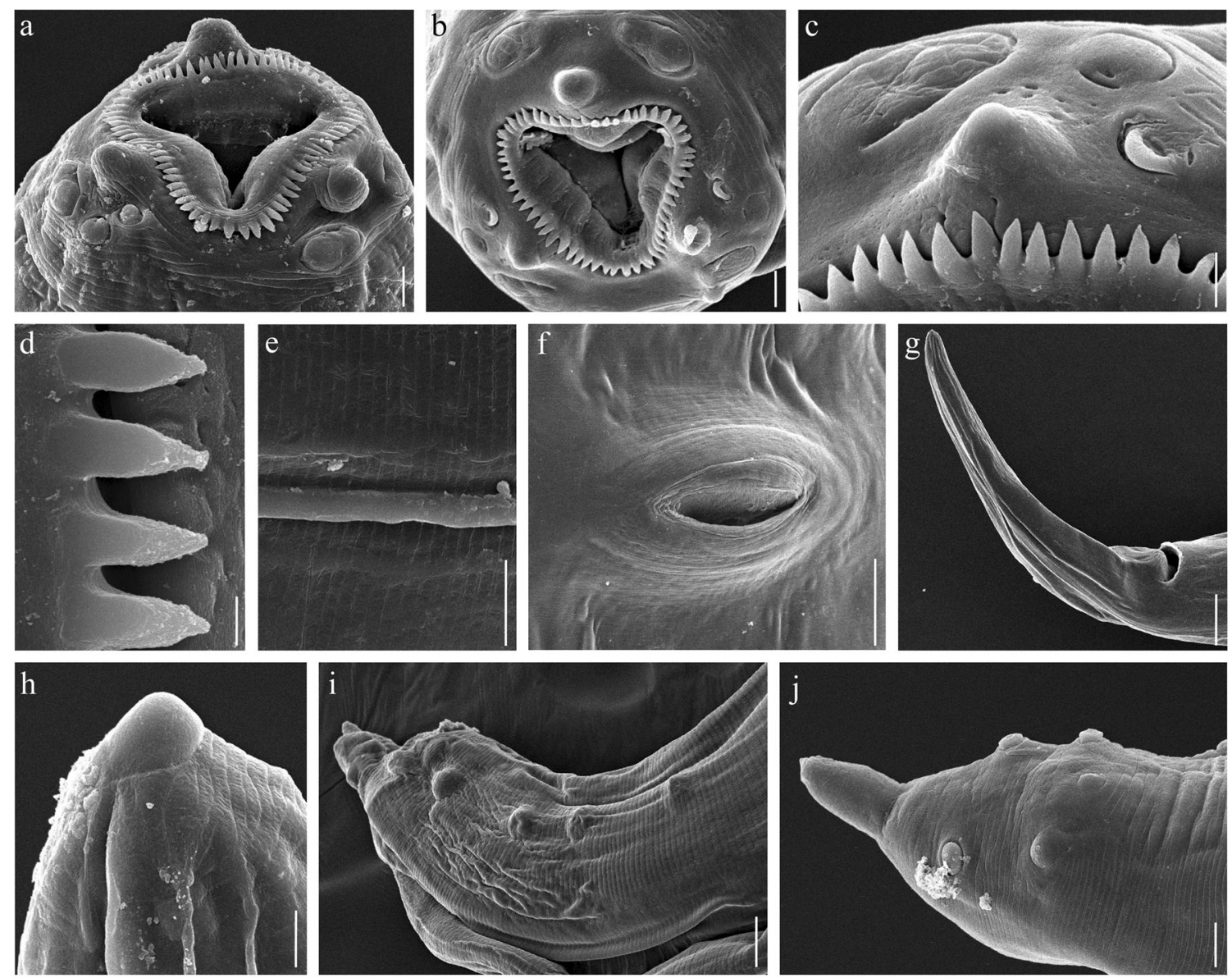
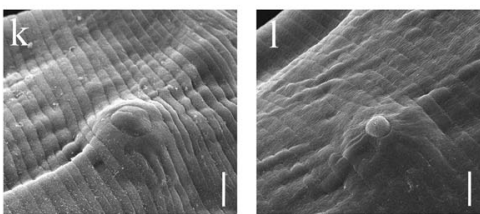

Fig. 2 Pseudanisakis argentinensis n. sp., scanning electron micrographs. a Cephalic end, subapical view. b Cephalic end, apical view. c Ventro-lateral lip showing cupola, single double papilla, single small papilla and amphid. d Detail of denticles. e Lateral alae and cuticle striations. f Vulva. $\mathbf{g}$ Posterior end of female. $\mathbf{h}$ Tail tip of female showing

\section{Remarks}

The general morphology of Pseudanisakis argentinensis $\mathrm{n}$. sp. closely resembles that of $P$. tricupola, the only other species in the genus bearing a cupola on each lip. However, $P$. argentinensis $\mathrm{n}$. sp. differs from $P$. tricupola, and from the remainder of the species of the genus, by having a greater number of precloacal papillae. Although there is a partial overlap in the ranges of the precloacal papillae between P. tricupola (6-9) and the new species (8-12), no individuals with 6 or 7 pairs were observed in the present work and $50 \%$ of examined males were out of the range of $P$. tricupola by bearing 10 or more pairs. Gibson (1973) recorded seven pairs of precloacal papilla in two males from $B$. brachyurops in the southern Southwest Atlantic. Unfortunately, no male worms
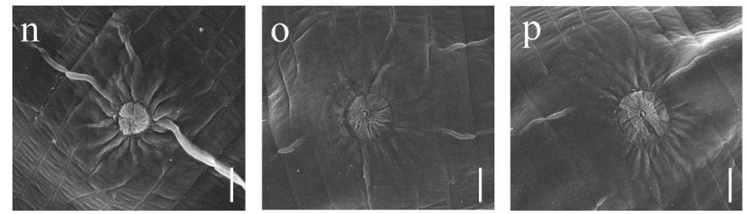

terminal knob. i Posterior end of male. $\mathbf{j}$ Tail of male. $\mathbf{k}-\mathbf{p}$ Precloacal papillae ordered from cloaca. $\mathbf{k}$ Papilla 1. I Papilla 2. $\mathbf{m}$ Papilla 5. $\mathbf{n}$ Papilla 8. o Papilla 10. p Papilla 11. Scale bars: $100 \mu \mathrm{m}: \mathbf{g} ; 50 \mu \mathrm{m}: \mathbf{f}$, i; $10 \mu \mathrm{m}: \mathbf{a}, \mathbf{b}, \mathbf{e}, \mathbf{j}-\mathbf{p} ; 5 \mu \mathrm{m}: \mathbf{c}, \mathbf{h} ; 2 \mu \mathrm{m}: \mathbf{d}$

were recorded in the 26 specimens of $B$. brachyurops herein examined, but the only worm found, a juvenile female, was confirmed genetically as belonging to the new species (see below). This author also observed some morphological and morphometric differences between specimens from $B$. brachyurops and those from $R$. radiata in the Northern Atlantic, which were considered to be a result of intraspecific variability and allometric growth due to the small number of specimens examined (two males and two females). These differences were a larger size of the females than those commonly found in $R$. radiata, a greater length-to-breadth ratio of the ventriculus, slightly longer spicules and the shape of the tip of tail in females. Three of these differences are here confirmed based on a larger number of specimens from different skate species and can be considered as diagnostic. Indeed, females 


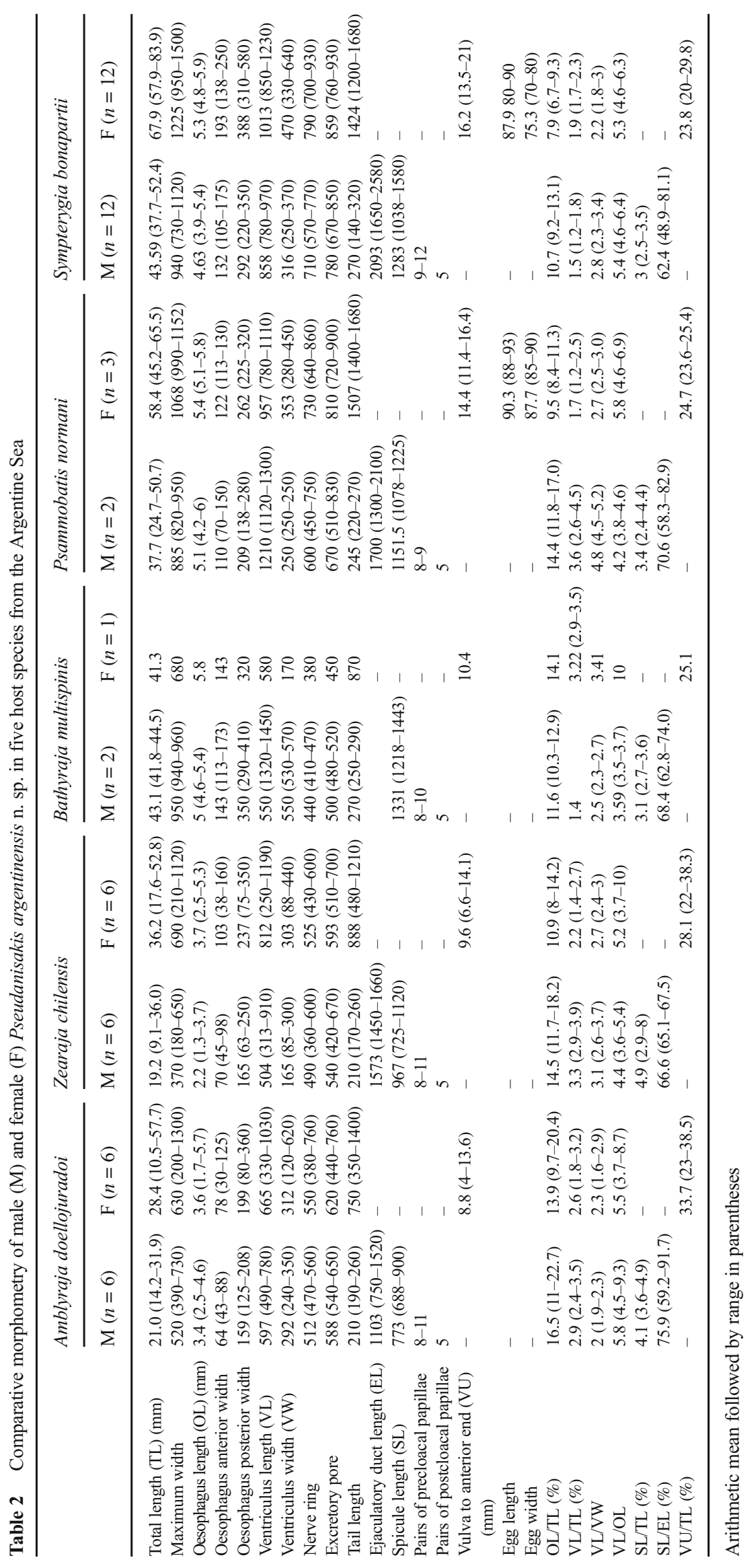


of $P$. tricupola ranged 5.9-57 $\mathrm{mm}$ in length (but 50-56 $\mathrm{mm}$ in the case of the two females from B. brachyurops described by Gibson 1973), whereas those of the new species measured $10.5-83.9 \mathrm{~mm}$. A larger size is herein also confirmed for males, measuring 9.1-52.4 mm, whereas the range of total length for those of $P$. tricupola from $R$. radiata was 5.4$34.5 \mathrm{~mm}$. The length-to-breadth ratio of ventriculus of the new species reached higher values of 2.62 (1.58-5.20) (males and females combined) than those from $R$. radiata (1.922.75 ) and which are in agreement with the values obtained by Gibson (1973) for worms from B. brachyurops (4.3-4.4). The presence of a small knob on the very tip of the tail in females, which is absent in P. tricupola, was confirmed in all of the specimens from Argentine waters, both females and males. Finally, Gibson (1973) observed longer spicules in the two males from B. brachyurops (1.4 and $1.6 \mathrm{~mm})$ compared with those of $P$. tricupola $(0.15-1.1 \mathrm{~mm})$, although both males were rather small in size (22 and $29 \mathrm{~mm})$. The spicules in the present material were also slightly longer (0.69$1.58 \mathrm{~mm}$ ), although spicule length tended to correspond with specimen length. Unfortunately, no spicule-to-total length ratios were provided by Gibson (1973), but, considering the variability in size of the worms between the different skate species and the allometric nature of spicule growth (see below), this trait seems to be an unreliable character for discriminating these species. Finally, $P$. argentinensis n. sp. has the second largest number of denticles surrounding the mouth (87), after P. sulamericana, which possess a maximum of 95 denticles.

\section{Morphometric analyses}

Both male and female nematodes showed insignificant differences between slopes across host species for any of the relationships analysed (both $p>0.01$ ). Allometric growth (slopes significantly different from 1) was observed for most relationships, with the exception of VL vs VW for males and VL vs OL for both sexes (Table 3 ).

\section{Sequence analyses}

There is no mtcoxl sequence of Pseudanisakis registered in GenBank, and consequently, a comparison between $P$. argentinensis n. $\mathrm{sp}$. and other species of the genus was not possible.

The mtcox 1 sequence length in the constructed alignment for all of the species was $598 \mathrm{bp}$. The K2P p-distances between all specimens of Pseudanisakis varied between 0 and $1.5 \%$ (mean $0.8 \pm 0.4 \%$ ), being similar to results between individual specimens of $A$. pegreffii, A. ziphidarum and T. canis, which ranged between 0 and $0.8 \%$. Mean distances
Table 3 Results of allometry tests between morphometric traits of Pseudanisakis argentinensis n. sp., including values of slope of the standardized major axis lines, correlation coefficient $\left(r^{2}\right)$ and significance level $(p)$

\begin{tabular}{|c|c|c|c|c|c|c|}
\hline & \multicolumn{3}{|l|}{ Males } & \multicolumn{3}{|c|}{ Females } \\
\hline & $p$ & $r^{2}$ & Slope & $p$ & $r^{2}$ & Slope \\
\hline OL vs TL & $<0.01$ & 0.847 & 0.724 & $<0.01$ & 0.815 & 0.627 \\
\hline VL vs TL & $<0.01$ & 0.778 & 0.731 & $<0.01$ & 0.754 & 0.718 \\
\hline VL vs VW & $>0.01$ & 0.675 & 0.968 & $<0.01$ & 0.881 & 0.805 \\
\hline VL vs OL & $>0.01$ & 0.741 & 1011 & $>0.01$ & 0.626 & 1144 \\
\hline SL vs TL & $<0.01$ & 0.745 & 0.708 & - & - & - \\
\hline SL vs EL & $<0.01$ & 0.759 & 0.718 & - & - & - \\
\hline VU vs TL & - & - & - & $<0.01$ & 0.938 & 0.736 \\
\hline
\end{tabular}

Codes for variables as indicated in Table 1; bold numbers indicate not significant differences

within groups of Pseudanisakis (i.e. for each host species) ranged between 0.7 and $1 \%$, and varied from 0.3 to $1.3 \%$ between these groups; these values were notably lower than those obtained between specimens of Pseudanisakis and sequences of the other genera, which ranged between 13.2 and $19.7 \%$ (Table 4). On the other hand, the p-distance values between congeneric species of Anisakis were also much higher (11\%). Interspecific and intraspecific genetic distances are readily apparent (Fig. 3 ).

The ABGD method clustered sequences into four groups, i.e. all of the specimens of Pseudanisakis which formed a single group, the two species of Anisakis and T. canis $(p<0.001)$. The ML tree clustered sequences into the same four groups as identified by the ABGD method, with the specimens of Pseudanisakis clustering together regardless of the host species. Finally, the MPTP method also delimited four species, grouping all of the Pseudanisakis sequences together.

\section{Discussion}

Since the establishment of Pseudanisakis as subgenus of Anisakis by Layman and Borovkova (1926), the genus has undergone several modifications in terms of concept and nomenclature (Yamaguti 1941; Mozgovoi 1950; Gibson 1973, 1983; Hartwich 1974; Sprent 1983; Petter et al. 1991). For some years, the genus remained relatively understudied, until the description of a new species, P. sulamericana (see Santos et al. 2004), and a morphological and molecular characterization of the poorly known $P$. rajae (see Li et al. 2012) were published. However, at a higher level the taxonomic status of Pseudanisakis still remains problematic, in part due to the lack of molecular studies needed to establish its position within Ascaridoidea (see Santos et al. 2004). Indeed, some authors 
Table 4 Averaged K2P pdistances of the partial mtcoxl gene sequence between Pseudanisakis argentinensis $\mathrm{n}$. sp. (Pa) from different hosts, Anisakis pegreffii (Ap), A. ziphidarum (Az) and Toxocara canis $(\mathrm{Tc})$

\begin{tabular}{lllllllll}
\hline \multicolumn{7}{c}{ Within groups } & \multicolumn{2}{l}{ Between groups } \\
\cline { 3 - 8 } & & $\mathrm{Pa} / \mathrm{ZC}$ & $\mathrm{Pa} / \mathrm{SB}$ & $\mathrm{Pa} / \mathrm{PN}$ & $\mathrm{Pa} / \mathrm{BB}$ & $\mathrm{Pa} / \mathrm{AD}$ & $\mathrm{Ap}$ & $\mathrm{Az}$ \\
\hline $\mathrm{Pa} / \mathrm{ZC}$ & 0.01 & & & & & & \\
$\mathrm{~Pa} / \mathrm{SB}$ & 0.008 & 0.008 & & & & & \\
$\mathrm{~Pa} / \mathrm{PN}$ & 0.007 & 0.007 & 0.006 & & & & & \\
$\mathrm{~Pa} / \mathrm{BB}$ & - & 0.005 & 0.004 & 0.003 & & & \\
$\mathrm{~Pa} / \mathrm{AD}$ & - & 0.012 & 0.013 & 0.008 & 0.012 & & \\
$\mathrm{Ap}$ & 0.004 & 0.191 & 0.195 & 0.191 & 0.192 & 0.197 & & \\
$\mathrm{Az}$ & 0.007 & 0.160 & 0.162 & 0.160 & 0.161 & 0.165 & 0.110 & \\
$\mathrm{Tc}$ & 0.006 & 0.167 & 0.169 & 0.168 & 0.167 & 0.171 & 0.135 & 0.132 \\
\hline
\end{tabular}

AD Amblyraja doellojuradoi, BB Bathyraja brachyurops, PN Psammobatis normani, SB Sympterygya bonapartii, ZC Zearaja chilensis consider Pseudanisakis within Acanthocheilidae Wülker, 1929 (see Hartwich 1974; Gibson 1983; Santos et al. 2004; Li et al. 2012), whereas others include it in Anisakidae (Railliet \& Henry, 1912) (Sprent 1983; Petter et al. 1991; Gibbons 2010). Further evidence based on different molecular markers will be necessary to confirm the position of Pseudanisakis among ascaridoids.

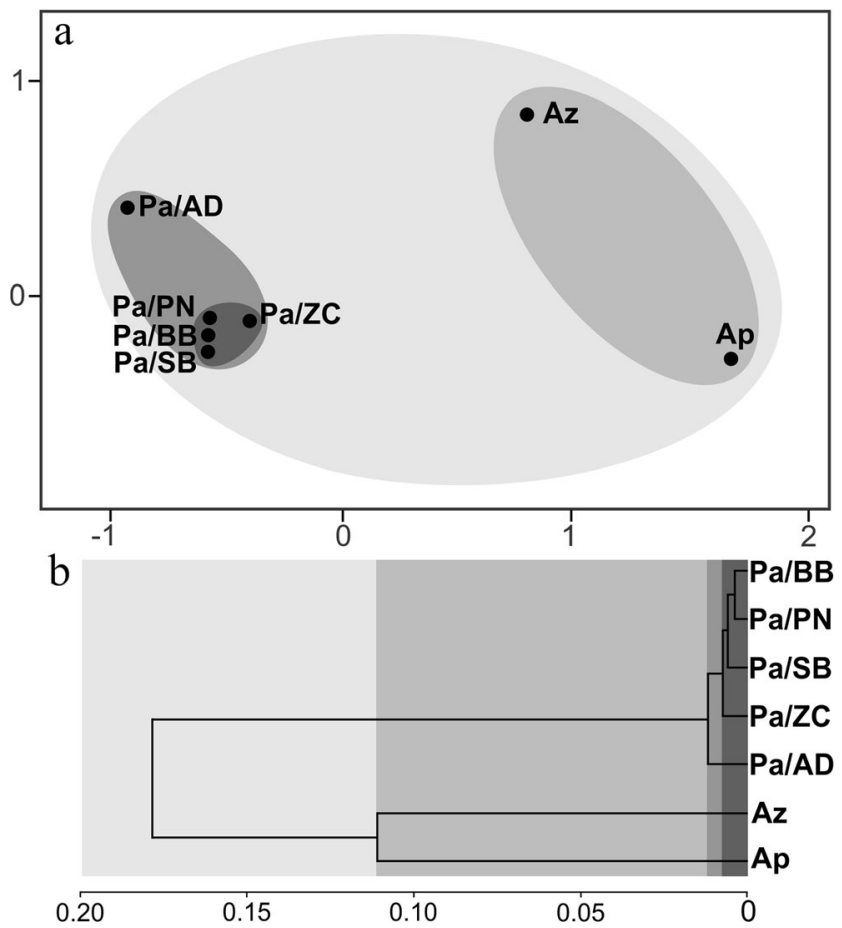

Fig. 3 Non-metric two-dimensional ordination plot and cluster analyses of K2P p-distances of the partial $\mathrm{mtcoxl}$ of Pseudanisakis argentinensis n. sp. and Anisakis spp. Results of a hierarchical agglomerative clustering are shown as dendrograms and overlaid on the MDS plot with similarity levels represented by a grey scale. Pa Pseudanisakis argentinensis n. sp. Az Anisakis ziphidarum. Ap Anisakis pegreffii. AD Amblyraja doellojuradoi. BB Bathyraja brachyurops. PN Psammobatis normani. SB Sympterygia bonapartii. ZC Zearaja chilensis
In addition to morphological and meristic traits, the systematics of nematodes has largely been based on morphometric characteristics and their ratios, especially at lower taxonomic levels. Specimens of the new species were found parasitizing six species of skates distributed over a wide latitudinal range $\left(34^{\circ} 24^{\prime}-53^{\circ} 30^{\prime} \mathrm{S}\right)$. These worms showed a high variability in size across host species, which could indicate that the species displays a high phenotypic plasticity or, alternatively, that more than one species of the genus could be present in different hosts. This second hypothesis is refuted here (see below); therefore, differences in size are considered as intraspecific variability, possibly resulting from differences in the suitability of various host species or other extrinsic factors. In fact, phenotypic plasticity has been suggested as a response to the host in other parasitic nematodes (Viney 2013).

As shown by Gibson (1973) for some morphometric features of $P$. tricupola, allometric growth was observed in the new species for most of the traits considered. Differences in growth rates for some characteristics were also evident between the sexes. Therefore, the slopes of the SMA-adjusted lines are recommended as variables for use in future intersexual and interspecific comparison. On the other hand, the relationships VL vs VW for males and VL vs OL for both sexes resulted isometric, and could be useful as species discriminators, depending on their isometry in other species.

Although allometry can vary, even among populations of a same species (Poulin 2009), and despite the variability in size of the worms recovered from the different skate species, there were no significant differences between the slopes of all of the analysed relationships, a result that can be interpreted as an evidence for conspecificity.

Morphological characteristics of nematodes often have restrictions when used to determinate the specific identity of some taxa, especially when the presence of sibling species is common. This is the case for the family Anisakidae, where molecular studies are indispensable for true specific identifications (Valentini et al. 2006; Mattiucci and Nascetti 2008). 
Despite that mtcox 1 is not often used for the recognition of anisakids (Mattiucci et al. 2008), this gene is routinely used for species discrimination in barcoding studies (Hebert et al. 2003a). Congeneric species of animals regularly possess substantial sequence divergence in their mtcoxl, whereas intraspecific divergence is rarely greater than $2 \%$ and, in most cases, is less than $1 \%$ (Hebert et al. 2003b). The maximum value of divergence observed for $P$. argentinensis n. sp., both within and between host species (1.3\%), lies within the range of intraspecific divergence. By contrast, divergence values between Anisakis species were notably greater $(11 \%)$. The low genetic divergence values found among specimens of Pseudanisakis indicate that all of the worms analysed belong to one and the same species, a result supported by the other measurements of species delimitation (ABGD and mPTP) applied.

Three of the six species identified as hosts of $P$. argentinensis $\mathrm{n}$. sp. have previously been reported to be parasitized by $P$. tricupola. These host records include two occurring in the Atlantic, B. brachyurops (see Gibson 1973) and $S$. bonapartii (see Tanzola et al. 1998), and one, Z. chilensis (as Raja chilensis), in the Golfo de Arauco, Chilean Pacific (Fernández and Villalba 1985), the latter of whom suggested that this parasite has a continuous distribution between Pacific and Atlantic waters. Considering the differences between P. tricupola and the new species, in addition to morphological and molecular analyses indicating the presence of a single species parasitizing the different skate species in the region, previous records of P. tricupola in South American waters are regarded as conspecific with $P$. argentinensis $\mathrm{n}$. sp.

Consequently, only $P$. sulamericana and $P$. argentinensis $\mathrm{n}$. sp. are considered to be present in South American waters, whereas $P$. tricupola and $P$. rajae are restricted to the Northern Hemisphere. These results are in accordance with the high level of endemism displayed by skate genera characteristic of South American waters (Figueroa et al. 2013). In fact, three of the six genera of skates parasitized by Pseudanisakis (Sympterygia, Rioraja and Psammobatis) are endemic to the Southwest Atlantic Ocean.

Despite the apparent low host specificity of the new species, it was not found in any of the 26 specimens of A. castelnaui examined; however, this may be attributed to an ecological rather than a phylogenetic specificity. In fact, the life-cycle of Pseudanisakis spp. is unlikely to include bony fishes as intermediate hosts, a role apparently played by crustaceans (Gibson 1973; Santos et al. 2004). Indeed, whereas most skate species herein examined are basically carcinophagous (Cousseau and Perrotta 2013; Bellegia et al. 2014, Estalles et al. 2016), A. castelnaui is mainly piscivorous, a predilection that increases as the fish grows (Barbini and Lucifora 2012), thus reducing its exposure to infective stages of Pseudanisakis.
Acknowledgements Thanks are extended to the Instituto Nacional de Investigación y Desarrollo Pesquero (INIDEP) and the Industrias El Corsario A.A., Mar del Plata, for providing fish samples, and to Dr. Santiago Barbini (IIMyC), Dr. Lorena Scenna (IIMyC) and Dr. Daniel Figueroa (UNMdP) for helping in the identification of skates and providing literature on chondrichthyans. Special thanks are due to the two anonymous reviewers for their valuable comments that helped to improve this article. Financial support was provided by grants from Consejo Nacional de Investigaciones Científicas y Técnicas (PIP No. 112-201501-00973), the Fondo para la Investigación Científica y Tecnológica (PICT 2015 No. 2013) and the Universidad Nacional de Mar del Plata (EXA 869/16). This work is part of the Doctoral Thesis of M.M.I., carried out in the Universidad Nacional de Mar del Plata, Facultad de Ciencias Exactas y Naturales.

\section{References}

Altschul SF, Gish W, Miller W, Myers EW, Lipman DJ (1990) Basic local alignment search tool. J Mol Biol 215:403-410. doi:10.1016/ S0022-2836(05)80360-2

Anderson MJ, Gorley RN, Clarke KR (2008) PERMANOVA+ for PRIMER: guide to software and statistical methods. PRIMER-E, Plymouth

Barbini SA, Lucifora LO (2012) Feeding habits of a large endangered skate from the south-west Atlantic: the spotback skate, Atlantoraja castelnaui. Mar Freshw Res 63:180-188

Belleggia M, Scenna LB, Barbini SA, Figueroa DE, Díaz De Astarloa JM (2014) The diets of four Bathyraja skates (Elasmobranchii, Arhynchobatidae) from the Southwest Atlantic. Cybium 38:314 318

Bush AO, Lafferty KD, Lotz JM, Shostak AW (1997) Parasitology meets ecology on its own terms: Margolis et al. revisited. J Parasitol 83: $575-583$

Clarke KR, Gorley RN (2006) PRIMER v6: user manual/tutorial. PRIMER-E, Plymouth

Cousseau MB, Perrotta RG (2013) Peces marinos de Argentina: biología, distribución, pesca. Instituto Nacional de Investigación y Desarrollo Pesquero INIDEP, Mar del Plata

Cousseau MB, Figueroa DE, Díaz de Astarloa JM, Mabragaña E, Lucifora LO (2007) Rayas, chuchos y otros batoideos del Atlántico Sudoccidental $\left(34^{\circ} \mathrm{S}-55^{\circ} \mathrm{S}\right)$. Instituto Nacional de Investigación y Desarrollo Pesquero, Mar del Plata

Díaz J, Villanova GV, Brancolini F, del Pazo F, Posner VM, Grimberg A, Arranz SE (2016) First DNA barcode reference library for the identification of South American freshwater fish from the lower Paraná river. PLoS One 11:e0157419. doi:10.1371/journal.pone.0157419

Estalles ML, Perier MR, Di Giácomo EE (2016) Trophic ecology of the smallnose fanskate Sympterygia bonapartii in the San Matías Gulf, northern Patagonia, Argentina. Ichthyol Res 63:207-217

Fernández J, Villalba C (1985) Proleptus carvajali n. sp. (Nematoda: Spiruroidea), new records and systematic list of the parasitic nematodes from fishes in Chile. Rev Chil Hist Nat 58:109-120

Figueroa DE, Barbini S, Scenna L, Bellegia M, Delpiani GE, Spath C (2013) El endemismo en las rayas de la zona común de pesca Argentino-Uruguaya. Fr Mar 23:95-104

Filatov DA (2002) ProSeq: a software for preparation and evolutionary analysis of DNA sequence data sets. Mol Ecol Notes 2:621-624. doi:10.1046/j.1471-8286.2002.00313.x

Folmer O, Black M, Hoeh W, Lutz R, Vrijenhoek R (1994) DNA primers for amplification of mitochondrial cytochrome $\mathrm{c}$ oxidase subunit I from diverse metazoan invertebrates. Mol Mar Biol Biotechnol 3: 294-299 
Gibbons LM (2010) Keys to the nematode parasites of vertebrates. Supplementary volume. CAB International, Wallingford

Gibson DI (1973) The genus Pseudanisakis Layman \& Borovkova, 1926 (Nematoda: Ascaridida). J Nat Hist 7:319-340

Gibson DI (1983) The systematics of ascaridoid nematodes - a current assessment. In: Stone AR, Platt HM, Khalil LF (eds) Concepts in nematode systematics. (Systematics association spec vol 22). Academic Press, London, pp 321-338

Hall TA (1999) BioEdit: a user-friendly biological sequence alignment editor and analysis program for Windows 95/98/NT. Nucl Acids Symp Ser 41:95-98

Hartwich G (1974) Keys to genera of the Ascaridoidea. In: Anderson RC, Chabaud AG, Wilmott S (eds) CIH Keys to the nematode parasites of vertebrates, no. 2. Commonwealth Agricultural Bureaux, Farnham Royal $15 \mathrm{pp}$

Hebert PD, Cywinska A, Ball SL, de Waard JR (2003a) Biological identifications through DNA barcodes. Proc R Soc Lond Ser B Biol Sci 270:313-321. doi:10.1098/rspb.2002.2218

Hebert PD, Ratnasingham S, de Waard JR (2003b) Barcoding animal life: cytochrome c oxidase subunit 1 divergences among closely related species. Proc R Soc Lond Ser B Biol Sci 270(Suppl 1):S96-S99. doi:10.1098/rsbl.2003.0025

Kapli P, Lutteropp S, Zhang J, Kobert K, Pavlidis P, Stamatakis A, Flouri T (2017) Multi-rate Poisson tree processes for single-locus species delimitation under maximum likelihood and Markov chain Monte Carlo. Bioinformatics. doi:10.1093/bioinformatics/btx025

Kekkonen M, Mutanen M, Kaila L, Nieminen M, Hebert PDN (2015) Delineating species with DNA barcodes: a case of taxon dependent method performance in moths. PLoS One 10:e122481. doi:10. 1371/journal.pone. 0122481

Kimura M (1980) A simple method for estimating evolutionary rate of base substitutions through comparative studies of nucleotide sequences. J Mol Evol 16:111-120

Layman EM, Borovkova MM (1926) [Parasitic worms of the skate (Raja radiata Don.) from material of the 15th Federal Helminthological Expedition.] Raboty Parazitologicheskoi Laboratorii. Moskovskii Gosudarstvennyi Universitet, pp. 9-26. (In Russian)

Li L, Gibson DI, Liu YY, Zhang LP (2012) Morphological and molecular study of the poorly known species Pseudanisakis rajae (Yamaguti, 1941) (Nematoda: Acanthocheilidae) from elasmobranchs in the Yellow Sea and Taiwan Strait off the coast of China. Syst Parasitol 81:115-123. doi:10.1007/s11230-011-9331-x

Mattiucci S, Nascetti G (2008) Advances and trends in the molecular systematics of anisakid nematodes, with implications for their evolutionary ecology and host-parasite co-evolutionary processes. Adv Parasitol 66:47-148. doi:10.1016/S0065-308X(08)00202-9

Mattiucci S, Paoletti M, Webb SC, Sardella N, Timi JT, Berland B, Nascetti G (2008) Genetic relationships among species of Contracaecum Railliet \& Henry, 1912 and Phocascaris Höst, 1932 (Nematoda: Anisakidae) from pinnipeds inferred from mitochondrial cox2 sequences, and congruence with allozyme data. Parasite 15:408-419. doi:10.1051/parasite/2008153408

Mozgovoi AA (1950) Notes on the foundation of the genus Pseudanisakis (Layman \& Borovkova, 1926) nov. gen. Trudy Gel'minti Labi 4:17-24 In Russian

Nei M, Kumar S (2000) Molecular evolution and phylogenetics. Oxford University Press, New York

Petter AJ, Paradiznik V, Radujkovic BM, Cassone J (1991) Redescription d'Acanthocheilus rotundatus (Ascaridoidea: Nematoda), parasite de requins (Pleurotremata: Selachii), considération sur les affinités du genre Acanthocheilus et conclusions taxonomiques. Ann Parasit Hum Comp 66:187-194
Poulin R (2009) Interspecific allometry of morphological traits among trematode parasites: selection and constraints. Biol J Linn Soc 96: 533-540

Previšić A, Gelemanović A, Urbanič G, Ternjej I (2016) Cryptic diversity in the Western Balkan endemic copepod: four species in one? Mol Phylogenet Evol 100:124-134. doi:10.1016/j.ympev.2016.04.010

Puillandre N, Lambert A, Brouillet S, Achaz G (2012) ABGD, automatic barcode gap discovery for primary species delimitation. Mol Ecol 21:1864-1877. doi:10.1111/j.1365-294X.2011.05239.x

Reiczigel J (2003) Confidence intervals for the binomial parameter: some new considerations. Stat Med 22:611-621. doi:10.1002/sim.1320

Rózsa L, Reiczigel J, Majoros G (2000) Quantifying parasites in samples of hosts. J Parasitol 86:228-232. doi:10.1645/0022-3395(2000) 086[0228:QPISOH]2.0.CO;2

Santos CP, Lent H, Gibson DI (2004) A new species of Pseudanisakis Layman \& Borovkova, 1926 (Nematoda: Ascaridida) from Rioraja agassizii and Psammobatis extenta (Rajidae) in Brazilian southwestern Atlantic waters. Syst Parasitol 57:229-235. doi:10.1023/B: SYPA.0000019086.44939.17

Sprent P (1969) Models in regression and related topics. Methuen, London

Sprent JFA (1983) Observations on the systematics of ascaridoid nematodes. In: Stone AR, Platt HM, Khalil LF (eds) Concepts in nematode systematics. (Systematics association spec vol 22). Academic Press, London, pp 303-319

Tamura K, Stecher G, Peterson D, Filipski A, Kumar S (2013) MEGA6: molecular evolutionary genetics analysis version 6.0. Mol Biol Evol 30:2725-2729. doi:10.1093/molbev/mst197

Tang CQ, Humphreys AM, Fontaneto D, Barraclough TG, Paradis E (2014) Effects of phylogenetic reconstruction method on the robustness of species delimitation using single-locus data. Methods Ecol Evol 5:1086-1094. doi:10.1111/2041-210X.12246

Tanzola RD, Guagliardo SE, Brizzola SM, Arias MV, Botté SE (1998) Parasite assemblage of Sympterygia bonapartei (Pisces: Rajidae), an endemic skate of the southwest Atlantic. Helminthologia 35:123129

Thompson JD, Higgins DG, Gibson TJ (1994) CLUSTAL W: improving the sensitivity of progressive multiple sequence alignment through sequence weighting, position-specific gap penalties and weight matrix choice. Nucleic Acids Res 22:4673-4680

Valentini A, Mattiucci S, Bondanelli P, Webb SC, Mignucci-Giannone AA, Colom-Llavina MM, Nascetti G (2006) Genetic relationships among Anisakis species (Nematoda: Anisakidae) inferred from mitochondrial cox2 sequences, and comparison with allozyme data. J Parasitol 92:156-166. doi:10.1645/GE-3504.1

Viney ME (2013) Life-history plasticity and responses to host defense. In: Kennedy MW, Harnett W (eds) Parasitic nematodes: molecular biology. Biochemistry and Immunology. CAB International, UK, pp $15-29$

Warton DI, Wright IJ, Falster DS, Westoby M (2006) Bivariate line-fitting methods for allometry. Biol Rev 81:259-291. doi:10.1017/ S1464793106007007

Warton DI, Duursma RA, Falster DS, Taskinen S (2012) smatr 3-an R package for estimation and inference about allometric lines. Methods Ecol Evol 3:257-259. doi:10.1111/j.2041-210X.2011. 00153.x

Yamaguti S (1941) Studies on the helminth fauna of Japan, part 33 Nematodes of fishes. II. Jap J Zool 9:343-396

Zhang J, Kapli P, Pavlidis P, Stamatakis A (2013) A general species delimitation method with applications to phylogenetic placements. Bioinformatics 29:2869-2876. doi:10.1093/bioinformatics/btt499 